\title{
NOT ANOTHER MORAL SUMMIT! PROBLEMS AND POSSIBILITIES FOR MORAL REGENERATION
}

\author{
Neville Richardson \\ School of Theology \\ University of Natal
}

\begin{abstract}
South Africa's new democracy has seen a number of high-level public meetings with morality as their central theme. The Moral Summit of 1997 has been followed in 2002 by the launch of the Moral Regeneration Movement. This has been an unusual and fascinating feature of South African public life. This paper seeks to examine the phenomenon - what is it, how did it arise, what is its intention, what is the nature of the moral discussion, and how effective has it been or is it likely to be? Of central importance for this paper is the role of religion in the process, and the changing nature of that role.
\end{abstract}

\section{Meetings of moral significance}

Since the inauguration of the new democracy in South Africa in April 1994, a number of major gatherings of a moral nature have taken place. Not all have called themselves "summits", but they qualify for consideration in this paper according to the degree of official involvement to the level of national government and, on occasions, the international political community. The agendas and discussions of these meetings could well be the subject matter of university and seminary ethics classes. Noteworthy here are the proceedings of the Truth and Reconciliation Commission (1997-1999), the Anti-Corruption Summit (1999), the World Conference Against Racism (Durban, 2001) and the World Summit on Sustainable Development (August 2002).

Another group of meetings, however, is even more central to the concern of this paper. These are meetings that have focussed directly on the moral condition of South African society. The Moral Summit of 1997, which was preceded by several workshops, was chaired by ex-President Mandela and attended by leaders of all significant religious bodies and political parties. It was to be followed by a second Moral Summit about six months later, but the response was extremely disappointing. ${ }^{1}$ There may have been many reasons for the poor response, including its succession so soon after the first summit, but it may be safely assumed that the response would have been much better had there been a general sense that something was being achieved by such summits.

Political leaders, however, persevered in their quest to address the morality of the nation. At a meeting in February 2002, State President Thabo Mbeki, Deputy President Jacob Zuma and Deputy Minister of Education, Smangaliso Mkhatshwa, expressed their "concern about the worsening moral situation." Invitations to workshops were sent out and this time, "their concern was confirmed by the overwhelming response from invitees across political, racial, religious, economic and gender spectra." 2

1. Approximately 150 invitations were sent out to individuals and institutions. Only 10 replies were received, of which 9 were negative. (Dr Franz Auerbach in telephone conversation, May 2002).

2. "Preamble" in Freedom and Obligation: A Report on the Moral Regeneration Workshops I \& II, July 2000, 
The subsequent workshops took place in late February and early May 2000. Deputy Minister of Education, Smangaliso Mkhatshwa describes their purpose: "Note that these workshops, in which I personally participated, did not focus on moral degeneration but on regeneration. The aim was to work towards the establishment of proactive measures to ensure that our country does not degenerate into a moral slum."3

The first of the workshops focussed on an analysis of the problem and recognised that unless there was clarity in understanding the problem, it would not be possible to respond effectively. Its report therefore, indicates a concern for precision, defining basic terms, even to the extent of pointing to the fine distinction between "morality" and "ethics". The second workshop affirmed the work of the first, but tackled the more practical tasks of setting national moral priorities, devising a national framework for moral regeneration, and setting up a steering committee to implement the process.

Flowing out of this process, the Moral Regeneration Movement (MRM) was launched in April 2002 in a specially prepared aircraft hangar at the Waterkloof Airforce Base, Pretoria. The relative austerity of the budget, reflected in the venue, was an intentional aspect of planning for the launch and the movement itself. ${ }^{4}$ The launch was attended by about one thousand people, ${ }^{5}$ including various national political leaders. The emphasis, however, was on bringing together as wide a spectrum of people as possible, from every province and every sector of society. Discussions centred on what was being done, should be done and could be done to bring about the moral regeneration of society. It was made very clear that the meeting was not an end in itself, but the launch of a process that must be carried through by the people themselves. In its concept and strategy, the Moral Regeneration Movement launch was a very different kind of meeting from the earlier Moral Summit. This difference will be discussed in section 3 below.

Moral intervention at such a high level of national political leadership is an unusual phenomenon. Cedric Mayson claims: "Nowhere else in the world today will you find a conference coming together from every sector in society committed to solve its moral challenges together." Mayson further claims for South Africa:

It is the only country with a National Religious Leaders' Forum where these leaders all meet together regularly, and meet twice a year with the President, to discuss common challenges. It is one of the few countries that openly admits it has problems, and the only one in which government and all sectors of civil society have embarked on a specific movement of Moral Regeneration."7

moralregeneration.htm.

3. Smangaliso Mkhatshwa, "Forword by the Deputy Minister", Freedom and Obligation: A Report on the Moral Regeneration Workshops I \& II, July 2000, moralregeneration.htm.

4. "The venue, an aircraft hangar at Waterkloof Airforce Base, was a welcome change from the usual five-star opulence of such gatherings" (The Natal Witness, editorial comment, 22nd April 2002). "The MRM launch cast R3 million, mainly in travel costs, and was funded by Government, which also voted R2 million...towards establishing the Movement. The initial four year programme will require support from many sectors of society." (Cedric Mayson. Interim Report on the Moral Regeneration Movement Launch, 19 April 2002, 2, n. 2, cpmayson@mweb.co.za). The hope is expressed that much of the implementation will take place in existing social groups and political institutions.

5. The Interim Report on the Moral Regeneration Movement says "about 900 people attended", while a private letter of 30th May 2002 claims "1300 came".

6. Cedric Mayson. "Interim Report on the Moral Regeneration Movement Launch", 6.

7. Cedric Mayson, "A Vision for South Africa" (Introductory material presented to the MRM launch, cpmayson@mweb.co.za): n. 8. 


\section{Why moral summits?}

What has given rise to the succession of moral meetings? The very fact that such meetings have been considered necessary, even urgent, and have been planned and executed at substantial cost, drawing on the time and energy of political leadership, is itself of notable moral significance. Not always noticed is the moral capacity of those responsible for recognising the problem and taking the initiative in addressing it. The first answer to the question must obviously lie in the moral condition of South African society. The meetings clearly point to the fact that there is an unacceptable level of immorality in the country, sufficient to be worrying to those concerned with and responsible for the economy, with tourism and the international image of the country, as well as with the general morale of the populace. ${ }^{8}$ The official preparatory document for the launch of the MRM gives the following account:

The moral assault on the majority of South Africans has left clearly visible manifestations of a society urgently in need of targeted and concrete efforts to extend the scope of the transformation process beyond the redefinition of our political institutions. The battle for the creation and sustenance of shared values for our society is a long-term challenge that we have to deal with. Some of these manifestations include high levels of murder; robbery and theft; rape, women and child abuse; abuse of people with disabilities; abuse of the elderly; domestic violence; widespread alcohol and drug abuse; drug trafficking; use of public office for personal gain; white collar crime.

The account continues with a catalogue of underlying structurally related problems "that Moral Regeneration efforts must confront":

The devaluation of people; racism in key societal institutions; sexism and gender oppression as practised by many South Africans in their daily lives, and in societal institutions and the socialisation of children; undermining and abuse of the Bill of Rights; breakdown of the family as a key social institution; huge gaps between the "haves" and "have-nots"; poor work ethic; culture of enrichment; individualism and selfishness; lack of integrity and honesty among some people in position of influence; perceptions of slow delivery to the poor; culture of entitlement; consumerism and materialism; high levels of poverty. ${ }^{9}$

One view refers to a "moral vacuum" in the country, with the implication that this has been caused by colonialism and apartheid. President Thabo Mbeki is quoted as saying that, following apartheid:

There was a collapse of an acceptable level of morality in our society which resulted in the elevation of the self, and the serving of the interests of the self to the point that self becomes a religion. The self became the god we must all worship ... In the vacuum individuals had to decide for themselves what was good and what was bad, and the

8. The following dramatic catalogue of immorality was Cedric Mayson's opening blast in his powerpoint presentation to the launch of the Moral Regeneration Movement on 18th April 2002, cpmayson@mweb.co.za. It has the ring of a prophet of ancient Israel, especially Amos. "Murder! Robbery and theft! Rape! Women and child abuse! Domestic violence! Drug trafficking! Fraud! Embezzlement of public funds! Crooked business dealings! Racism! Muggings! Hijacks! Gangsters! Abusing the Bill of Rights! Laziness! Collapse of the family! Land hunger! Lack of will to resist evil! The growing gulf between haves and have nots! Selfishness! Moral collapse! Corruption from police to parliament! Are our leaders fit to govern? Slow delivery! Perverted religion! Backbiting! Greed!"

9. Moral Regeneration Framework (South African Government Discussion Document, Daniel Moagi, Department of Arts, Culture, Science and Technology, 2002), 4-5. 
good was defined as what would serve my interests. ${ }^{10}$

While there can be no doubt that these socio-economic influences have created an emphatically undesirable moral context, it would seem to be simplistic and reductionist to regard social morality as entirely constituted by socio-economic factors. Likewise, in his address at the launch of the Moral Regeneration Movement, Smangaliso Mkhatshwa strongly emphasises the contextual factors. He says:

$[\mathrm{N}] \mathrm{o}$ talk of moral degeneration or moral crisis in South Africa can make sense unless the history of the country is taken cognisance of. This helps to put the problem in a proper perspective. Ours is a history of oppression, of racial discrimination and dehumanisation, of poverty, of institutionalised- and counter-violence, of the breakdown of family life through mobility control laws and violence, and more importantly, the decision of the youth to take the responsibility of liberating our country upon themselves ...We are indeed reaping the fruits of our past ...

But, significantly, Mkhatshwa also calls for something new, something beyond the previous context.

However ... are we to dwell on this past, or are we to move on into a better future? This is a very relevant question because most social deviants tend to justify their anti-social behaviour by claiming to be products of an oppressive apartheid system. They now feel entitled to whatever they were never able to get before. In the final analysis, the reality is that we are sitting with a generation or two which needs community support structures in order for them to function in this new context. ${ }^{11}$

Mkhatshwa's salutary description of this moral context, with its apartheid past and moral vacuum in the present, is that it is a ticking moral time bomb!

The second answer lies in the distinctive nature of South Africa's public life. If one can speak of a "national psyche", that psyche is shaped by a unique mix of politics and religion. If one can describe South Africa's unfolding national life as a drama, then politics and religion have been key players. Richard Elphick says: "Christian doctrine, language and sentiment are ... interwoven in the social and cultural history of South Africa." ${ }^{12}$ While Christianity was indeed the dominant religious influence in the past, other religious faiths were present. The previously muted multi-faith nature of South African society was emphatically heralded in the multi-faith prayers at the inauguration of President Mandela in April 1994, and was enshrined in the principles of religious freedom laid down in the Constitution of May 1996. This new dimension did not arise without a great deal of background work by the World Conference on Religion and Peace and the National Religious Leaders' Forum. ${ }^{13}$

10. Cedric Mayson. "Interim Report on the Moral Regeneration Movement Launch", 19 April 2002, 4.

11. "The Nature and Extent of the Problem" in Freedom and Obligation: a Report on the Moral Regeneration Workshops I \& II

12. Richard Elphick, "Introduction: Christianity in South African History", in Christianity in South Africa: a Political, Social and Cultural History, Richard Elphick and Rodney Davenport (eds.). Cape Town; Oxford: David Philip; James Currey, 1997, 1.

13. For ten years prior to the inauguration of the new democratic South Africa in 1994, certain initiatives brought together leaders of the various religions in South Africa, with a view to influencing the embryonic democratic process. These were the annual Desmond Tutu Peace Lecture, the World Conference on Religion and Peace, the 1993 National Peace Initiative with its National Peace Accord and, in 1994, the establishing of the National Religious Leaders' Forum. There can be little doubt that these initiatives had a marked influence on the coming to birth and early shaping of post-apartheid South Africa. In particular, the Declaration on Religious Rights and Responsibilities (1993) in particular seems to have contributed significantly to the place of religion in the new Constitution. I am grateful to Gerrie Lubbe for his personal reminiscences of the role of 
The third answer is that the moral meetings of national significance are the offspring of a longstanding church-state tension. Since the onset of apartheid in 1948, South Africa's public life has been the subject of intense scrutiny by a succession of meetings and official statements of a moral and theological nature. Successive assemblies of the World Council of Churches (WCC), led by the second assembly at Evanston, USA in 1954, condemned racism in church and society and, by 1970, that ecumenical body had established a Programme to Combat Racism with Southern Africa as its focus. At the end of 1960, in the wake of the Sharpeville massacre, the South African member churches called on the WCC to convene a meeting to deal with the problem of race relations in the country. The resultant Cottesloe Consultation and its challenging statement evoked a hostile response from the Prime Minister of the day, Dr HF Verwoerd, which was the occasion of the Dutch Reformed Churches withdrawing from membership of the WCC. In 1968, the South African Council of Churches published the Message to the People of South Africa, declaring apartheid to be "a false gospel". This was followed by the SPROCAS initiative - the Study Project on Christianity in Apartheid Society. In 1982, the World Alliance of Reformed Churches famously declared apartheid to be a heresy. In 1985 the Kairos Document was published. These are some of the moral peaks in a landscape of church-state tension in South Africa's recent past. Alongside them have been numerous less prominent meetings - moral foothills of a regional or denominational nature. Major meetings dealing with matters of serious moral concern therefore, were established as a dramatic feature of South Africa's public, political and ecclesial landscape prior to the emergence of the "new South Africa" in 1994. The moral summits that followed the advent of the new democratic South Africa are simultaneously the continuation of an established tradition and the facing of the new post-apartheid social situation in which the Christian churches seem to play a far less prominent role than before.

\section{Are moral summits morally effective?}

The 1997 Moral Summit was impressive, not only in the fact that such a gathering occurred at all, but in its being initiated by top political leadership, its being chaired by ex-president Mandela, and the encouraging attendance by a wide spectrum of political and business leaders. Its aim was to influence society from the top, and its main means of achieving this was the issuing of a Code of Conduct that it hoped would be signed by the widest possible range of leaders. The Code is explicit as to its target group. It declares itself to be "for persons in positions of responsibility". Signatories commit themselves to the following ten high-sounding principles: integrity, incorruptibility, good faith, impartiality, openness, accountability, justice, respect, generosity, and leadership. ${ }^{14}$

For a number of reasons it seems that the high hopes for the Moral Summit were not realised. Mention has already been made of the extremely poor response to the attempt to mount a follow-up Moral Summit. Clearly the Summit lacked an adequate follow-up strategy. Secondly, statements alone, no matter how clearly and strongly worded, are notoriously ineffective as strategies in a moral cause. ${ }^{15}$ Thirdly, and closely related to the previous point, is the questionable relationship between public declaration and moral motivation. Fourthly, a catalogue of abstract moral principles without a descriptive context is superficial to the point of

religion in this vital formative period.

14. As well as being signed by political leadership, the Code of Conduct was also signed on suitably publicised occasions by councils of major municipal centres such as Durban and Johannesburg.

15. This was the main thesis of my study on ecumenical social ethics relating to race issues in R N Richardson. The World Council of Churches and Race Relations 1960-1969: a Study of Thought and Action. Frankfurt: Peter Lang, 1977. 
meaninglessness. This point has been emphatically made by Alasdair MacIntyre. ${ }^{16}$

The Moral Regeneration Movement (MRM), while addressing the same broad moral concerns, is different from the preceding Moral Summit in both concept and strategy. In its rationale it is to a large extent a critique of its predecessor, and it is significant in this regard that the official government document for the MRM does not even mention the 1997 Moral Summit as one of the steps leading to the launching of the MRM.

The key factor of the MRM is that the initiative is not imposed from the top, but taken up by the different sectors of society working together in each Province, Metro City and Municipality, and in each sector, and be taken into existing structures. ${ }^{17}$

There is an impressive plan of implementation that envisages Provincial Consultations taking place within three months of the launch, and to report on their progress. A full-time national co-ordinator will be appointed, and the MRM will be established as an independent Section 21 company "supported by all sectors and government". "Towards the end of the year a National Conference will be held, and the Working Committee reconstituted as a National Council." 18

The intention is to educate all sectors of the public in terms of the social values enumerated in the preamble to the national Constitution, and the Moral Regeneration Movement seems to do well in its plan of implementation in two major respects. First, it declares itself to be a movement from the bottom up. This distinguishes it from its predecessor, the Moral Summit, of addressing the political and business leadership in the illusory belief that any hoped-for moral improvement at leadership level will trickle down to the rank and file. Secondly, and consistent with the first point, it has no intention of setting up a national body to reform the nation's morals. It recognises that such reform is only possible if it is achieved by the people themselves, working in and through their existing organisations. The MRM is to be commended for these two vital moral insights that the moral urgings of leaders alone count for very little if they do not find resonance in the existing moral strivings of the people, and that working with people as individuals alone does little for the building of social morality. In its declared intention to implement moral growth through social organisations, there seems to be every possibility that the MRM will have more success than its predecessors in its goal of developing "an ethos, spirit and commitment to a higher moral social order". ${ }^{19}$

\section{The call for a new spirituality}

The 1997 statement of ex-president Mandela has a memorable ring: "In our striving for political and economic development, the ANC recognises that social transformation cannot be separated from spiritual transformation." What is pointed to here is the need for something more than lists of values and hopeful social and economic schemes. The highest sounding values and best laid plans are nothing without the profound commitment and motivation of those who should act upon them. It is at this level that the words "spiritual transformation" are of vital importance.

It is fascinating that this call is made, not by religious leaders, but by politicians. The introductory material of the Moral Regeneration Movement noted that the previous Moral Summit had been organised by politicians, and added:

16. Alasdair MacIntyre. After Virtue 2nd ed. 1984; and Whose Justice? Which Rationality?, 1988, both Notre Dame: University of Notre Dame Press.

17. Cedric Mayson. "Interim Report", 19 April 2002, 2.

18. Cedric Mayson. "Interim Report", 2.

19. Moral Regeneration Framework, 8. 
The present initiative on moral regeneration is also the initiative of politicians. Ironically, the religious sector which should have taken the initiative, seems to have taken a back seat ... There seems to be a lack of concerted and co-ordinated action from most religious leaders in promoting the struggle against immoral behaviour. ${ }^{20}$

The religious sector is rightly criticised for erroneously regarding itself as "the sole custodian of moral values", and alternative avenues are sought to develop the desired spirituality. Cedric Mayson sees the problem as springing from a focus on religious institutions to the detriment of "the inspiration of our religions; the spiritual values which unite us." 21

If spirituality is seen as being so vital to moral renewal what, precisely, is the spirituality that is referred to? As is clear in the statements above, it is not the spirituality of the identifiable "religious sector". The religious institutions are heavily criticized for failing in their assumed role of religious leadership. There is a reaching out for an indigenous "African spirituality", with its $u b u n t u^{22}$ values, in place of the imported spirituality with its individualism and materialism, which are seen as playing a major part in the moral damage done to Africa. Apart from a pointing in the direction of African spirituality, however, nothing of substance is said of the kind of spirituality required to regenerate the moral life of society.

The term accompanying "spirituality" in Mandela's call, is "transformation" and this term must bear similar scrutiny. It must also be noted that if what is sought is a spirituality that produces moral transformation, such transformation does not come easily or painlessly. The reshaping of moral lives is often described in the language of religion as "conversion", and pain is an unavoidable accompaniment of moral conversion, on at least two levels. First, there is the pain of moral beginnings, of setting out on a new journey in which the change is not only to the landscape but also to oneself. This is the pain of starting out on discipleship, and is probably what Jesus had in mind when he addressed a crowd of followers and spoke in typical rabbinic hyperbole:

Whoever comes to me and does not hate father, mother, wife and children, brothers and sisters - yes, even life itself, cannot be my disciple. Whoever does not carry the cross and follow me cannot be my disciple (Luke 14:26-27). ${ }^{23}$

Secondly, there is the pain of making unpopular moral stands, such as being a whistleblower against corruption or, in some communities, declaring one's HIV positive status in order to warn others against a similar fate. The vital question to be asked at this point is what resources our society has both to account for the pain and to deal with the pain that accompanies moral conversion. Certainly much of what passes for morality in our secular humanist society is unable to give adequate answers to this question. The dominant social ethic in modern society seems to promote such values as progress, success, achievement, and happiness. It puts forward an attractive "morality" that serves mainly to enhance the good life - an "add-on" morality. In the face of moral demand, sacrifice and

20. "The Nature and Extent of the Problem" in Freedom and Obligation: a Report on the Moral Regeneration Workshops I \& II

21. Cedric Mayson. "Interim Report", 19 April 2002, 6.

22. Ubuntu is a term that denotes a rich African concept meaning something like humaneness, compassion, generosity, fellow-feeling. It is encapsulated in the sense of profound communality in the African phrase: "a person is a person through other people". Although long established in African tradition, since the emergence of the new democracy in South Africa ubuntu has grown in popularity almost to the point of becoming a cliché in moral discourse.

23. Quoted from the New Revised Standard Version, 1989 
pain, however, such morality is found wanting.

The learning of a new way of life, for spiritual and moral transformation can be nothing less, can not be embarked on alone. Just as "community support structures" are rightly called for in the case of the morally lost generations, ${ }^{24}$ so such structures are needed if spiritual and moral transformation is to take place. What, however, are these communal structures to be if not the maligned religious institutions? If we are to discard these discredited institutions for the sake of some undefined "spirituality", where is this spirituality to be found? It cannot be in some lonely individual quest, the heroic sovereign individual conscience of the European Enlightenment, for that individualism and its accompanying "liberal" political attitudes are explicitly and emphatically rejected. If neither in some institution, nor in an individualist quest, where is the required spirituality and morality to be found and exercised?

\section{The need for moral community}

Morality does not exist alone, in some majestic purity. It is an essentially communal phenomenon. For morality to be thought about, understood, taught and leant, there must be moral community. Describing how values are transmitted, the official MRM document correctly states:

We do not learn in isolation, but in communities of association, such as the family, the education system, and peer groups called social institutions by some people.

It adds:

We internalise these values through the socialisation process. It is probably true to say that values acquired in and reinforced by institutions are more meaningful and lasting, and that those learnt outside of these tend to be ephemeral, superficial and momentary."25

The MRM's acknowledgement of the community-relatedness of morality is to be applauded. It signals a clear move away from western individualism. Yet in its reference to "values" that may or may not be internalised, may be learnt inside or outside of community, it is still trapped in western notions of the possibility of morality without community. The point of view of this paper is that morality requires community both at the conceptual and practical levels - moral understanding is always in relation to some discernible and describable community, and moral transformation and practice require the teaching, training and encouragement that only a moral community can provide.

What then is the nature of moral community? An immediate observation is that size does matter. A social entity as large as a nation cannot realistically claim the status of moral community for two reasons. First, it is too populous for the kind of communication between its members which moral community requires. Secondly, it is too diverse in cultures, religions and local allegiances to make any sense of the term "moral community" - this is the case even in monocultural nations, therefore definitely not the case in South Africa's vast social and cultural diversity. Conversely, too small a community, such as a modern nuclear family, may have the capacity for coherence and communication that a nation lacks, but from where does it draw its traditions, convictions and allegiances? A family cannot be its own moral community. That is not to say that a family cannot be moral, for a family can indeed be an intense centre of moral discourse and education. The point is that a family alone can not be the source of its own morality. It needs to be embedded in some greater

24. See the earlier quotation from Mkhatshwa on this point.

25. Moral Regeneration Framework (South African Government Discussion Document, 2002), 13. 
moral whole that is larger than the family, especially in terms of moral resources and traditions.

The deepest need is for the widespread experience of moral community, with a profound sense of belonging (not only to a group, as in a family or team); in a continuity which includes ongoing accountability (not just to an occasional intense collective experience, such as a football crowd); not only to clearly identifiable moral reference points (as in a code or pledge), but to a morality as embodied in the community's common life with its "saints" or exemplars. Such a community should be sensitive to and engaged in the public life of the wider society within which its own life is embedded, but it should not merely mirror that society nor feel its continuing existence to be threatened as the social whole undergoes change (as is usually the case after a particular challenge is over - a war or a social struggle). It is understandable that Cedric Mayson should worry about where the struggle ethic has gone - with its camaraderie and the accountability. It is not enough for people to join together merely for some particular limited end, even one as serious as a war or a struggle for justice. Ultimately, such a grouping is merely a matter of convenience, a means to an end, however noble that end may be. This is a central weakness of the Hobbesian approach to moral community - it cannot exist for anything more than a limited purpose, a purpose not in itself moral, and its basis is a "social contract".

\section{The spiritual nature of moral community}

Clearly, as the image of such a community starts to form in our minds, we realise that the kind of community that meets these requirements may well be described as a religious community. That does not necessarily imply adherence to one or other of the major religions, but it does imply that such moral community must be of a religious nature where the social embodiment of one's deepest convictions are to be found. A grouping or organisation that is established as a means to some particular, limited end, such as a commercial company, a sports club, or a political party, does not fulfil the requirements of moral community, even though it may pursue its ends in a moral manner. The strong likelihood, given the requirement of historical continuity, is that such moral community will indeed be the expression of one of the major religions. Certainly a flash of inspiration, however intense, or the invention of some new creed, however creative, is highly unlikely to provide either moral coherence (for concepts) or moral sustainability (for people engaged in the moral struggle). Cedric Mayson rightly abhors the institutional imprisonment of much religious life today, but surely creativity (in terms of what?) and recollections of the struggle alone are not going to provide the depth of spirituality, the long-traditioned convictions, and the ritualised memories we need for moral transformation. Therefore a movement for moral renewal should indeed be dissatisfied with institutionalism and look rather for moral community.

A priority of such a moral community in a society drastically in need of moral renewal, must surely be its capacity to transform people at a moral level. Again, as noted above, adherence to a moral code or pledge is not enough in itself, unless the communal depth of the terms "code" and "pledge" are recognised. Those terms have a hollow ring, if they refer to words on paper or to lists of moral resolutions alone. Moral codes have their proper place as shorthand forms of the moral boundaries of particular communities. A pledge, even more so, suggests a statement of serious commitment to a person or group. The Ubuntu Pledge, issued by the National Religious Leaders' Forum, seems better than the Moral Summit's Code of Conduct, in that it is addressed to the widest range of moral agents, not only leaders. Yet it also seems to imagine a moral realm separate from moral community. Too 
easily in our individualist climate of thought, we overlook the communities that are far more than merely the "social dimension" of our morality. They are the essential building blocks of our morality, they also provide us with the conceptual tools and practical energies for the building of our moral world. If there is to be moral transformation of people through moral community, then that community must be significantly different from the wider society previously shaping, inadequately, the morality of the people. It must be, in morally significant respects, a counter-community, an alternative society - never forgetting, however, its embeddedness in and its sensitivity to the wider society. The Declaration on Religious Rights and Responsibilities issued by the World Conference on Religion and Peace in 1994 seems to strike the right note in pointing out that religious communities have moral responsibilities to society, and especially in its insistence that whatever moral service or educational function the various religious communities offer to society should be "in accordance with their particular teachings". ${ }^{26}$

\section{Christian social witness in a multi-faith society}

It may be looking by now that this argument is moving in the direction of Christian morality, but that should not be surprising in a society that is majority Christian. The closing claim of this paper would be that Christian ethics, properly understood and embodied in witnessing communities of faith, has the potential to make a great moral contribution to the morality of South African society. Such a crusading claim, however, requires immediate qualification in at least three respects. First, it must be observed that Christianity in South Africa is far from being a united community - it is fragmented by rampant denominationalism, perhaps more so than any other country in the world. It is difficult to imagine the Christian voice in South Africa being a united voice. ${ }^{27}$ Secondly, it must be remembered that Christian churches in the past have been in serious moral error in their social witness in South African society. Not only have some denominations been declared heretical in terms of their own doctrine in their support for apartheid ${ }^{28}$, but others have been shown to be captive to the economic powers of colonialism ${ }^{29}$. Thirdly, it must be acknowledged that the Christian faith is one religious faith among many in South Africa ${ }^{30}$. Christian communities must, on the basis of their own faith, seek closer understanding and co-operation with other faith communities. Encouraging instances of such co-operation have happened to the good of the whole society, and hold out great promise for future social harmony. ${ }^{31}$

26. Declaration on Religious Rights and Responsibilities. World Conference on Religion and Peace, 1994.

27. "Christianity is extremely diverse. The conventional Western churches represent fewer than half of South Africa's population. Deep divisions, both political and doctrinal, run through South African Christianity." GC Oosthuizen, JK Coetzee, JW de Gruchy, JH Hofmeyr, BC Lategan (eds.) Religion, Intergroup Relations and Social Change in South Africa. Pretoria: Human Sciences Research Council, 1985. 101. The same work indicates (p.44) that the African Independent Churches are by far the fastest growing group. Institutionally, however, this Christian grouping is highly diverse, with some sources estimating about 3000 separate churches (see R Omond. The Apartheid Handbook. Harmondsworth: Penguin, 1985. 221.

28. See David Bosch, "Nothing but a heresy" in J de Gruchy and C Villa-Vicencio (eds.) Apartheid is a Heresy. Cape Town: David Philip, 1983. 24-38.

29. JR Cochrane. Servants of Power: the role of the English-speaking churches 1903-1930. Johannesburg: Ravan Press. 1987.

30. The national census conducted in 1980 showed that while the total percentage of (nominal) Christians in South Africa is $77 \%$, Muslims comprise $1.1 \%$, Hindus $1.7 \%$, and Jews $0.4 \%$. It should be noted that although the bare statistics indicate relatively small numbers of adherents of religions other than Christian, these are often grouped in urban areas and therefore have a significant social profile. African traditionalists are included in a group of $18 \%$. See GC Oosthuizen et al (eds.) Religion, Intergroup Relations and Social Change, 19-21.

31. For instance, during the "Seven Days War" in Pietermaritzburg and district, 25th-31st March 1990, 
Finally, for the sake of their contribution to the morality of society, it is important that Christian communities in South Africa develop a minority mindset. Faiths other than Christian, of course, are not in a numerical position to think of themselves as anything but minority faiths. Christianity, however, can claim to be numerically in the region of three quarters of the population. Two questions, however, must be asked of such a claim. First, which particular Christian institution or denomination would see itself as having an absolute majority over against all other Christian denominations and other faiths? This question raises the point about rampant denominationalism, noted above, and reminds those who would claim majority status for Christianity that effective majority is not as selfevident as it may appear at face value. Secondly, if majority status is to be claimed for Christianity, then why is its moral influence so evidently lacking? In matters of public debate, such as abortion and the use of condoms in the face of the HIV/AIDS crisis, the Christian voice is notoriously divided. Furthermore, if Christianity is the dominant social presence some may imagine it to be, then why the need, felt even at the highest levels of political leadership, for Moral Summits? Indeed, the more of an effective majority Christianity imagines itself to be, the greater should be its acknowledgment of failure as a moral influence in present South African society.

Majority status, however, is not about numbers alone. It is more a matter of dominance through institutional connections to political and economic power. Since the Constantinian revolution in the fourth century, this arrangement has tempted the church into too close an association with the dominant powers of society, thereby laying the foundation for the development of "civil religion" and the concomitant weakening of a distinctive Christian social witness. ${ }^{32}$ In South Africa, churches have aspired to dominant status in spite of the fact that since the Cape Parliament's passing of the Voluntary Bill in 1875, there has been no officially established church in South Africa. The 1996 Constitution, with its recognition of the multi-faith nature of South African society, makes it even more unrealistic for any religious institution to imagine itself still to hold officially favoured status. Learning to live in symbiosis with other faiths is a new and morally enriching challenge for the Christian churches in South Africa, but one that many churches will struggle to meet.

This closing call for a conscious change to a minority mindset, however, has more to do with social-ethical witness than with numbers of adherents. Whether numerically large or small, the Christian community in any society should always envisage itself as a minority, thereby avoiding the Constantinian temptation of too close a relationship with the powers of the day and the loss of distinctiveness and definition in Christian social witness. The difference such a change of mindset can make to the social acceptability and moral engagement with ordinary people, is well illustrated in Samuel Wells' account of his local church's involvement in the public initiatives for a better local society in Britain. His point is not about numbers but about attitude and approach, as is clear in his statement:

The power of the church is not that of the parent - greater resources, more experience, greater physical strength; instead, the church's power is that of the child - stubbornness and doggedness, and the tendency to ask awkward or embarrassing questions. So when

representatives of Muslim, Hindu and Christian communities came together to assist the thousands of refugees, many of whom were accommodated in the buildings of religious communities.

32. For an account of the rise of civil religion in South Africa in both English speaking and Afrikaner churches, see J de Gruchy. The Church Struggle in South Africa. David Philip: Cape Town, 1979. 32-35; also, for a more detailed account of the development of Afrikaner civil religion, see T Dunbar Moodie. The Rise of Afrikanerdom: Power, Apartheid and the Afrikaner Civil Religion. Berkeley: University of California Press, 1975 . 
the time comes to sit down with other groups in the community, the church sits down as a child, still learning, potentially disruptive, rather than as a parent, saying "come to where we already are". 33

\section{Conclusion}

Moral summits are a remarkable feature of the public life of post-apartheid South Africa. That there is an urgent need for such high profile meetings is a matter for grave concern, but that the matter is being taken so seriously by top political leadership is encouraging. The Moral Regeneration Movement is clearly and intentionally not another moral summit. To its great credit, the MRM searches in practical democratic fashion for moral community, yet it seems not to recognise the fundamentally religious nature of that quest. As South African political initiatives seek to improve public morality, the various faith communities should consider themselves as profoundly challenged. To what extent can they, collectively, work together to the common good? To what extent may they respectively be described as moral communities, faithfully living out their social witness in the body of a nation struggling to recover from the social cancer called apartheid?

33. Samuel Wells, "No abiding inner city: a new deal for the church" in Mark Thiessen Nation and Samuel Wells (eds.). For Faith and Fortitude: In Conversation with the Theological Ethics of Stanley Hauerwas. Edinburgh: T\&T Clark, 2000. 123. 